Anastazija Kirkova-Naskova

UDK 81'355:37.091.3

Ss. Cyril and Methodius University, Skopje

DOI: 10.4312/vestnik.11.119-136

Republic of North Macedonia

akirkova@flf.ukim.edu.mk

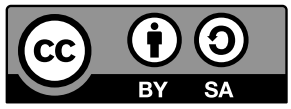

\title{
SECOND LANGUAGE PRONUNCIATION: \\ A SUMMARY OF TEACHING TECHNIQUES
}

INTRODUCTION

Despite the fact that pronunciation is recognized as a crucial component of second language (L2) learning, classroom practice shows that it is largely underestimated as a language skill in the curricula across language programs. The marginalization of pronunciation is most likely a result of teachers' choices not to teach it as equally as other language skills, on the one hand, and the lack of appropriate exercises in the textbooks, on the other. Teachers who are native speakers do not necessarily have specialist training in teaching L2 pronunciation, and in time they develop tolerance to their learners' pronunciation errors. Teachers who are non-native speakers are unaware or insecure about their own pronunciation, and pay more attention to practicing other language skills or grammatical structures (Henderson et al. 2012; Kirkova-Naskova et al. 2013).

Such a state of affairs is no surprise at all: one cannot expect practicing teachers to have a clear understanding of the theoretical approaches to teaching L2 pronunciation, as well as the capacity to put them into practice, when there remain contradictions and disputes among these approaches. For instance, a major issue that raises opposing views is whether pronunciation should be practiced as a separate or integral language skill. In this respect, some authors feel that pronunciation should be taught as a separate language skill with a strong focus on the acquisition of L2 sounds through developing good motor skills and accurate articulation (Brown 1987). Others believe that pronunciation is an inseparable part of the communicative process (Pennington and Richards 1986), and point out that precedence should be given to intelligible rather than accurate pronunciation, especially given the multidimensional nature of L2 speech reflected in perceptual phenomena such as accentedness, intelligibility and comprehensibility (Munro and Derwing 1995 1998 1999; Derwing and Munro 2005).

Another methodological issue that has aroused a fair number of opinions concerns the right approach to teaching and learning pronunciation. According to Celce-Murcia, Brinton and Goodwin (2007: 2), two general approaches have emerged as dominant in the field of modern language teaching: a) the intuitive-imitative approach, and b) the 
analytic-linguistic approach. The basic premise of the intuitive-imitative approach is that learners are capable of listening and imitating L2 prosody and sounds, thus implicitly acquiring the phonological system of the target language. The approach also assumes that they are exposed to a standard pronunciation model, presented by a teacher or audio equipment, resulting in their developing acceptable pronunciation. The main principle of the analytic-linguistic approach is that learners clearly benefit from explicit instruction of the L2 sound system. A variety of teaching tools facilitate this process, such as charts with phonemic symbols and vocal apparatus, detailed descriptions of articulatory movements, L1-L2 contrastive information, etc.

When defining the purpose of teaching and learning L2 pronunciation, the principle of nativeness clashes with that of intelligibility (Levis 2005). Proponents of the nativeness principle argue that acquiring native speaker competence is the goal of L2 pronunciation learning. In recent years it has become evident that such a view is unrealistic and imposes a huge burden on both teachers and learners. Indeed, even though research shows that few learners succeed in achieving this goal, the nativeness principle is still nurtured in practice, mostly because it can be conveniently compared to a referent native pronunciation model and because of learners' desire to overcome foreign-accented speech. Advocates of the intelligibility principle emphasize its simplicity in language use - learners need to be comfortably intelligible when interacting with native and non-native speakers (Kenworthy 1990; Morley 1991; Dalton and Seidlhofer 2001; Celce-Murcia, Brinton and Goodwin 2007). Research shows that the degree of accentedness of one's speech does not impede spoken communication; in fact, mildly-accented speech, and in some cases even strongly-accented speech, is perfectly intelligible and comprehensible to native speakers, and it is more likely that prosodic mispronunciations hinder communication rather than mispronounced L2 segments (Munro and Derwing 1995, 1999).

Different views aside, scholars agree that teachers' task is to help learners in understanding the link between the sounds and meaning in general, as well as the physical aspect of L2 sounds and the corresponding phonological concepts. Teaching L2 pronunciation entails selective focus on those elements that are relevant for successful communication - for instance, understanding the reduced forms of words is very important for effective communication in English (Cauldwell 2013). In line with the changing trends, pronunciation teaching techniques have been modified and prioritized. Therefore, this paper aims to give an overview of both traditional and alternative techniques for the teaching and practice of L2 pronunciation.

It is difficult to single out the most efficient pronunciation technique because the choice depends on the aim of the practice. When evaluating teaching materials, teachers should 
consider learners' needs and the pronunciation difficulties they face so that they can choose and/or modify the exercises that are potentially most beneficial for them. With this in mind, they have to make several decisions concerning the different linguistic properties of pronunciation as a language skill, the methodological approach of the exercise and the additional cognitive skills that learners develop in the learning process (see Figure 1).

\section{phonological structure:}

- phoneme

- syllable

- word stress

- sentence stress

- connected speech

- rhythm

- intonation

\section{type of instruction:}

- focus-on-forms (FonFS)

- focus-on-form (FonF)

- focus-on-meaning (FonM)
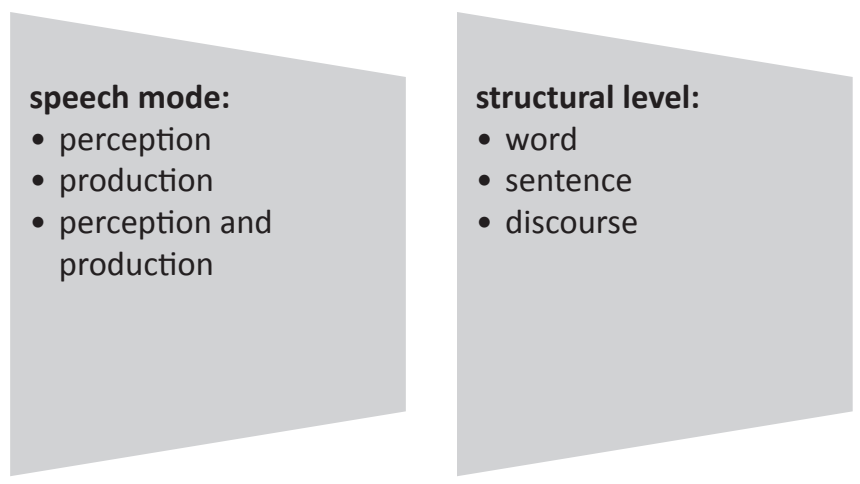

degree of control:

- complete control

- partial control

- spontaneous practice cognitive skills:

- noticing

- discriminating

- imitating

- reproducing

- contextualizing

- generating

- correcting

Figure 1. Linguistic, methodological and cognitive elements that need to be considered when choosing activities for pronunciation practice

The first decision a teacher has to make is what type of phonological structure to practice. Ideally, a teacher is expected to explain the different components of pronunciation or the 'building blocks' and the way they are related to each other. Foreign language courses usually start with units related to the smallest phonological structures, the individual phonemes of the language, and gradually progress to more complex structures such as word and sentence stress, features of connected speech rhythm and intonation. This creates a false notion in learners' minds that phonological structures function separately. The reality is quite the opposite - pronunciation acquisition is more meaningful if approached as a whole i.e. if learners are taught that the structures of the sound system 
function inseparable from each other and that "all aspects of pronunciation are needed right from the start" (Marks and Bowen 2012: 11). For instance, in English, the syllable is the basic unit of the rhythm group and contains a vowel as its peak. The syllables alternate between stressed and unstressed syllables in such a way that the nucleus placement (i.e. the prominence of the tonic syllable) depends on the relevance of the intended message. Understanding this process not only helps learners improve their listening skills, but it also strengthens their awareness of the English rhythmic structure. Moreover, the English rhythm itself is closely related to vowel length, especially their full quality in stressed syllables or reduced quality in unstressed syllables in certain grammatical words (pronouns, modals, prepositions, determiners). Being aware of this further helps learners to better hear, understand and pronounce word stress. Pronunciation is like a puzzle, where every piece gets its meaning when combined with the others. Therefore, the teacher should carefully select the phonological structures that require attention and then choose multifaceted activities (a wide range of activities are proposed in Kenworthy 1990; Laroy 1995; Hancock 2005; Hewings 19932007 2011; Vaughan-Rees 2003; Rogerson-Revell 2011; Marks and Bowen 2012).

Once the phonological structure is defined, the teacher should focus on the speech mode (perception only, production only or both perception and production) to be practiced by the activity, as well as the structural level of analysis (whether the phonological structure is to be examined at the word, sentence or discourse levels). Choosing the specific type of instruction ${ }^{1}$ is another decision a teacher has to make. Saito $(2012: 845,846)$ distinguishes between the following three types: a) focus-on-formS (FonFS) - the activity is controlled (decontextualized) and the accurate use of the phonological structure is practiced (for example, a mechanical drill of words where the only goal is to practice the form); b) focus-on-form (FonF) - the aim of the activity is to practice form not only in controlled contexts but also within the wider communicative context; and c) focus-on-meaning (FonM) - the focus of the activity is solely on the communicative task and the form is practiced implicitly. The type of instruction also determines the degree of control of the structure that is practiced: complete control, partial control or spontaneous practice.

Furthermore, it is of utmost importance that learners recognize that by practising a particular structure or 'form', they develop additional cognitive skills that help them acquire the elements of pronunciation more easily (Rogerson-Revell 2011: 212). One cannot expect learners to pronounce sounds or sound clusters that they have not heard before. Learners have to learn to notice phonological forms in speech so that they can be aware of the differences between their own speech and the speech produced by native speakers and/or advanced non-native speakers. Learners' perception is strengthened by performing perceptual discrimination and identification exercises; they learn to discriminate

1 Instruction is generally classified as implicit and explicit. The classification under the parameter type of instruction in Figure 1 is made based on the focus of the activity. 
the differences between the L1-L2 sound systems, or, more precisely between 'correct pronunciation' (speech that is very similar to the native speaker norm) and 'incorrect pronunciation' (speech that deviates from the native speaker norm). In order to develop automatic motor skills for precise sound production, learners need to be able to imitate the sounds (de-contextualized drills and repetition of L2 sounds is a particularly significant phase in the initial stages of language acquisition). At the same time, learners should try to produce sounds until they resemble the target pronunciation model, thus enabling themselves to reproduce sounds without encouragement or correction. Learners are often able to reproduce sounds precisely in isolation but not in connected speech. Therefore, they should be offered many opportunities for sound practice in context so that their pronunciation can gradually become intelligible and spontaneous. This way, they enable themselves to generate acquired phonological structures in different or similar phonetic environments i.e. in new words and phrases. In this respect, activities that include problem-solving and rule-forming objectives are especially beneficial. Such a process of learning and skill acquisition is complete when learners are able to correct their own pronunciation errors by practising activities that promote individual or peer evaluation.

To summarize, pronunciation teaching and learning is a complex task, and needs to be approached systematically in language courses. The literature in the field of L2 pronunciation teaching (specialist textbooks, books focusing on teachers' professional development, resource books, research papers) offers a variety of teaching techniques to facilitate this process. In the following section a selection of pronunciation teaching techniques is presented. The techniques are categorized and their main features are first described and then critically evaluated.

\section{3}

\section{TYPES OF PRONUNCIATION TEACHING TECHNIQUES}

\subsection{Automatic repetition and imitation}

Despite the assumption of being out-dated, automatic (mechanical) repetition and imitation of speech sounds are the most common pronunciation techniques, and play a key role when encountering new speech sounds. For instance, accurate pronunciation of new sounds requires developing new motor habits that in time develop as skills at the level of an automatic response. Such skills can be acquired with frequent regular practice, but if learners' attention is focused on the content only and not on the form, they may be neglected and this could directly affect learners' pronunciation (Rogerson-Revell 2011: 23). In sum, automatic repetition and imitation aims at gradual improvement and accurate speech production.

This technique follows a basic procedure: listen $\rightarrow$ repeat with imitation $\rightarrow$ say it in a different context. The teacher's role is to pronounce a word or a structure (or play 
an audio recording of a native speaker); the learners have to attempt to imitate what they heard. It is highly recommended that the repetition is choral at first and all learners are encouraged to participate. This way, their self-confidence is increased as the practice is anonymous and they are not publicly exposed (Kelly 2003). The next step is individual repetition when the teacher has the opportunity to give a corrective feedback. Repetition can be done with substitution i.e. learners replace one segment with another to form a different word, or even as pair work where learners practice sound repetition in a question-and-answer session (Byrne 1997; Kelly 2003).

Minimal pairs, words that differ in a single sound as in pin-bin-tin-kin-fin-sin, are considered the best type of exercise for practising sound repetition. They are used when practising both perceptual discrimination and sound articulation in different phonetic contexts, and can be modified in many creative ways (a selection of various minimal pair activities can be found in Kenworthy 1990; Dalton and Seidlhofer 2001; Kelly 2003; Baker 2006a 2006b; Celce-Murcia, Brinton and Goodwin 2007; Nilsen and Nilsen 2010; Rogerson-Revell 2011; Gilbert 2012). In order to avoid the monotony of drilled repetition, Bowen (1980) suggests incorporating minimal pairs in a specific situational context with or without visual aids so that the exercise has an overall more meaningful effect the teacher first presents key words and then introduces a sentence where the words of the minimal pair can be alternately used and the learners are required to provide the answer that matches what they heard, for example, The blacksmith is heating/hitting the horseshoe with a) the fire; b) the hammer (Bowen,1980: 65). Minimal pair exercises may be practiced in the form of games, such as bingo or following a set of instructions to reach a particular goal (Hewings 2011).

Another type of repetitive drill is backchaining and/or frontchaining i.e. sentences are gradually built up starting from the last word (backchaining) or the first word (frontchaining) and then adding the next word or phrase in the thought group (Lewis and Hill 1999; Kelly 2003; Mańkowska, Nowacka and Kłoczowska 2009). Such exercises are particularly effective for practising nucleus placement (tonic syllable), intonation and reduced word forms in longer phrases or sentences. Tongue twisters are also useful for sound repetition because they demonstrate one sound or two similar sounds in close sequence (Walker 2010). For mastering the rhythm patterns, it is recommended that learners recite poems (children's rhymes or nonsense poems), read poetry, speeches, or dialogues aloud, or perform plays (Celce-Murcia, Brinton and Goodwin 2007; Hancock 2017d).

It seems that repetition and imitation are an important aspect of pronunciation practice, and a suitable teaching technique for all age groups. However, though frequently used it is not a favourite technique because it is tedious and does not guarantee that learners would apply the phonetic structure consistently when speaking. Nevertheless, many experts agree that it is an important first step in understanding simple phonetic structures, which then becomes a good basis for mastering more complex ones (Lewis and Hill 1999; Kelly 2003). 


\subsection{Perceptual training (ear-training)}

The aim of perceptual training or 'ear-training' is to strengthen the sensitivity of the hearing mechanism so that learners can better process acoustic signals. This is because accurate perception is a prerequisite for accurate sound imitation - learners should learn to perceive L2 sounds first and then attempt to produce them (MacCarthy 1967; Dalton and Seidlhofer 2001; Cauldwell 2013). However, the L1 perceptual sound system is the main obstacle to precise L2 sound recognition - when learners are exposed to the sounds of another language they perceive the novel sounds through the filter of their L1 sound system (Flege 2003). Thus, a process of sound reorganization has to take place where learners need to be exposed to phonemic and phonetic contrasts between the two systems in order to be able to notice subtle differences. This is the main goal of perceptual training. The training itself encompasses different language domains - from phoneme differentiation to exposure and adaptation to different L2 language varieties.

Typical perceptual exercises include primarily L2 sound discrimination and identification in minimal pairs, as well as noticing different stress and intonational patterns. Discrimination and identification exercises vary in format, but in essence they are quite similar - the former require that a learner should listen to two sounds, words, phrases or sentences and decide whether they are the same or different, whereas the latter require that a learner should listen to one sound, a word, a phrase or a sentence and then identify that sound, word, phrase or sentence among similar sounds, words, phrases or sentences in a previously given list. Such minimal pair exercises are used to contrast not only two similar L2 sounds, but also L1-L2 sounds (Rogerson-Revell 2011).

Phonemic transcription is another activity that is used for ear-training. For example, transcribing nonsense words focuses learners' attention on individual sounds, whereas transcribing words in isolation or in a text focuses learners' attention on allophonic variation, phonotactics and connected speech processes (García Lecumberri and Maidment 2000; Tench 2011). Authentic audio and video recordings present abundant resources for developing teaching and practice materials for the perceptual training of a particular phonetic structure, or simply for exposing learners to the speech of native speakers of various regional and dialectal backgrounds.

Perceptual training is a crucial stage in L2 pronunciation acquisition. It is difficult to determine whether perception precedes production or vice versa, nevertheless, it seems that a great deal of exposure to L2 sounds and varieties naturally leads to better L2 sound production. All the techniques described in this section can be used with any age group if adapted appropriately. However, practice shows that minimal pair discrimination/identification activities are more suitable for young learners due to their better brain elasticity with regard to recognizing different sounds and intonation patterns, unlike adult learners who might get discouraged as a person's ability to easily recognize speech sounds is gradually lost as they grow older (Reid 2016: 24). On the other hand, adult learners better 
handle phonemic transcription exercises, because they have greater linguistic experience and more proficient cognitive skills they can rely on in the learning process.

\subsection{Phonetic instruction}

Phonetic instruction is specialist training in the phonetics and phonology of a particular language adapted to the requirements of L2 teaching. It includes activities such as use of phonetic and phonological terminology to classify L2 sounds, to describe the position of articulators and the manner of their formation as well as to explain L2 phonological rules and/or other relevant speech phenomena. Various teaching aids are also frequently used, for instance, vowel diagrams, tables with consonants and consonantal clusters, illustrations showing intonation contours, pictures with different tongue and lip positions, sagittal section of the position of the articulators for individual sounds (see Hancock 2005; Baker 2006a 2006b), etc.

Learning the phonemic symbols that correspond to the L2 sounds of the target language is a necessary step in phonetic instruction, as they are used both for presentation of L2 sounds and for practice (Underhill 2005). The activities with phonemic symbols are graded in format: in the beginning symbol-to-sound is practiced, then transcription of words and sentences and, at more advanced levels, transcription of short texts (García Lecumberri and Maidment 2000; Tench 2011). Familiarization with the phonemic symbols enables learners to check the pronunciation of new words in a dictionary by themselves (given the complexity of the English spelling system), to understand more vividly the rules of sound adaptation in connected speech, and, with the help of additional tonetic marks, to grasp L2 prosody (Wells 2006). More analytical exercises with phonemic symbols include word sorting by a particular sound, word association with a particular sound, and inductive reasoning to form a phonological rule (Hewings 2011). Recent technological advances make way for the use of online dictionaries as particularly useful resources for autonomous learning (Longman Dictionary of Contemporary English Online 2018; Cambridge Dictionary 2019; Oxford Learner's Dictionaries 2019; Macmillan Dictionary 2009-2019; Collins Online Dictionary 2019). These dictionaries list word entries with phonemic transcription and accompanying sound files in both British and American pronunciation, thus enabling learners to check their pronunciation and/or phonemic symbol command.

Phonetic instruction is also used to contrast the phonological systems of L1 and L2: first, error analysis is carried out following a diagnostic evaluation of potential problematic areas between the two sound systems. Such an approach is particularly effective with monolingual classes of L2 learners.

Research studies investigating the effectiveness of phonetic instruction report an overall positive effect on learning mainly because such explicit instruction "orients 
learner's attention to phonetic information, which promotes learning in a way that naturalistic input does not" (Thomson and Derwing 2015: 14). Most of the related studies are conducted with adult learners leaving a gap in research findings about the effectiveness of such technique with young learners. In addition, it is relevant to note that these studies have not yet proposed a unified approach applicable to different teaching contexts.

\subsection{Activities for raising phonological awareness and self-awareness of one's own speech}

Being aware of the relevance of pronunciation in spoken communication is a vital step in its effective acquisition. Learners of a second/foreign language cannot expect to be understood if they speak in an unintelligible or monotonous way. Teachers should help learners recognize their mispronunciations and motivate them to improve their overall L2 speech given the emotional and sociolinguistic effects of pronunciation on the pragmatics of spoken message.

In the early stages of learning, it is recommended that learners are encouraged to think about the language they study in relation to: a) their own speech and pronunciation difficulties; b) the importance they give to pronunciation; c) the pronunciation model they prefer; d) the degree of competence they aim to achieve (native or non-native speaker competence); e) any stereotypical prejudices they have and, if yes, how they might overcome them; f) their self-confidence when they speak; g) how they perceive the L2 language, i.e. the range of emotions they experience towards it; and so on. Thinking about these issues is very constructive - learners clarify their attitudes towards relevant topics they may not have thought of before, whereas teachers gain a valuable insight into learners' belief systems and their language learning goals, which helps them choose appropriate activities. Questionnaires are ideal for initiating such discussions. They can be of different format: with given multiple-choice answers, with blank spaces to fill in, or with open-ended questions that can be responded to in pair or groupwork activities (Kenworthy 1990; Laroy 1995; Hewings 2011).

The position of articulators, which gives the characteristic voice quality, is typical for every language. It is a concept that we approach intuitively when we give informal remarks about the way a language sounds or how someone speaks. Speakers of the same language position their speech organs in the same way (more detailed examples in Rogerson-Revell 2011: 38, 39) - helping students become aware of this can be done with appropriate exercises such as breathing and muscle relaxation exercises, exercises for jaw, tongue and lip positioning, whispering or loud speaking exercise, exercises with deliberate prolongation of the inherent length of a sound and many more (Wrembel 2001; Underhill 2005; Celce-Murcia, Brinton and Goodwin 2007; Rogerson-Revell 2011; Gilbert 2012; Hancock 2017a). Catford (2001) believes that learners can benefit from 
becoming conscious of the tactile and proprioceptive sensations associated with speech organs when sounds are produced: "It is absolutely useless merely to be aware of them intellectually... one must carry out a great deal of silent introspection concerning these sensations..." (Catford 2001: 120). He suggests silent practice of sounds with the help of a pocket mirror so that learners can connect the visible movements and positions of the tongue and lips with the proprioceptive sensations, as well as the auditory sensations we feel when sounds are pronounced with whisper or with voice. Underhill (2005: 114) recommends exercises for proprioceptive sound repetition and forming a mental image: "We have the ability to hear a sound externally and then to hear it again internally for several seconds... Only when we discover these latent learning faculties in ourselves do we have the possibility and the confidence to help our learners make use of them. Our mainstream procedures tend to recognize and value only the external processes that can be directly perceived by the teacher. By being unaware of, and unresponsive to, the inner processes, we lose an opportunity to interest learners in their own learning and in the discovery that they can rely on themselves more than they thought."

It is of utmost importance that learners raise their phonological awareness of the relevant L2 language structures and rules, as well as the awareness to care for their own speech. In addition to exercises that practice or contrast language structures (Kenworthy 1990; Laroy 1995; Hewings 2011), it is recommended that learners analyse their speech and get corrective feedback from the teacher - this enables them to become aware of their own pronunciation errors and to decide for themselves what aspects of their pronunciation they should improve. Getting constructive feedback should not inspire a negative feeling in learners; in fact, according to Morley (1991), learners should be able to learn how to correct themselves while the teacher should hint what and how should be corrected. Many authors advise making an audio and/or a video recording of learners' pronunciation, both individually and in interaction with another speaker, and then listen critically to the recordings i.e. analyse them in detail (Fraser 2001; Goodwin 2001; Kelly 2003; Celce-Murcia, Brinton and Goodwin 2007). These activities are particularly constructive for adult learners, as they enable them to critically assess their own pronunciation. Young learners, on the other hand, are not equipped with the necessary analytical skills to tackle such activities; nevertheless, if a game-like element is added, for instance impersonation or role-play, then they might prove very successful.

Once learners feel more confident in their knowledge of a particular pronunciation model, it is useful to raise their awareness of other regional, dialectal or sociolinguistic language varieties by including activities that expose them to diverse authentic speech. For instance, given the global expansion of English, learners should be aware of the differences between the regional varieties of the 'Inner Circle', i.e. traditional varieties of English that are primarily spoken in a country as L1 and are referred to as norm-providing varieties: British, Scottish, Welsh, Irish, American, Canadian, Australian, New Zealand English, and South African English, as opposed to the varieties of the 'Outer Circle', 
i.e. new varieties of English that have become official second language in a country and are referred to as norm-developing: Indian English, Chinese English, and other variants that have developed in former US and UK colonies (Kashru 1985). Also of note in this context is the emergence of International English or English as a Lingua Franca, an amalgam variety used in international communication in countries where English has played neither historical nor political roles (Jenkins 2000).

\subsection{Communicative activities}

Communicative activities focus on a specific phonetic structure in an interactive context. They help learners prepare for everyday situational use of L2 outside of the classroom and gradually reduce their dependence on the teacher's speech, which is usually the main pronunciation model learners are exposed to.

Their format varies. Games, for instance, are particularly popular as they contain an element of fun and occupy learners' attention through a set of interesting rules that must be followed - at the same time learners spontaneously practice the intended phonetic structure. Most games, either competitive or problem-solving, can be played individually, in pairs, in groups or as a whole class (for a variety of games intended for adult learners see Hancock 2010; Hancock 2017b, Hancock 2017c; for games intended for young learners see Nixon and Tomlinson 2009). Games encourage social interaction, as when playing bingo, cards, and Ludo or solving crosswords, anagrams, etc. Illustrations, drawings, cartoons and comics may be used to prompt word pronunciation, sentence formation or even develop a whole story (Trim 2001). They usually take the form of information gap activities, where learners lack the information needed to complete a task or solve a problem and have to communicate with other learners in the group to fill in the gaps. For instance, one learner has to describe a picture that has to be drawn by another learner, or learners have almost identical pictures that they have to describe and find the differences between. Mortimer (1995) recommends the practice of short pre-recorded dialogues that resemble everyday situations - this way, learners are not only exposed to authentic speech but also memorize chunks of speech, which they can optionally reproduce in a recorded version of the dialogue with pauses for the learners to respond or say the exact phrase. Hewings (1993) proposes tasks that require detailed description to start a conversation. Giving instructions (based on a map to find something or to describe a process) or finding out about the missing information (in tables or gapped text) are examples of activities that stimulate interaction of the question-and-answer type. For more advanced levels it is recommended that learners participate in group discussions or debates on a given topic, which gives them the opportunity to practice both phonetic structures and fluency (more detailed examples of such activities are included in Celce-Murcia, Brinton and Goodwin 2007: 291-295). In fact, any type of authentic material, such as 
advertisements, popular songs, restaurant menus, magazine articles, book excerpts, etc., may be used for practising different aspects of pronunciation through giving comments or engaging in conversation.

Classroom practice shows that communicative activities are beneficial for any age group, as they encourage speaking and interaction in a more realistic context.

\subsection{Interdisciplinary techniques}

In addition to traditional activities, recent pronunciation pedagogy marks a trend in experimenting with other innovative techniques adapted from other scientific disciplines, such as psychology, neurolinguistics and dramatic arts (Wrembel 2001; Celce-Murcia, Brinton and Goodwin 2007). These techniques are suitable for all age groups and add variety to conventional classroom practices.

Drama techniques are especially efficient as they create a friendly atmosphere where learners feel free to express themselves, thus reducing their affective filter and enhancing their self-confidence. Such techniques include voice modulation and sound sequence articulation, exercises for pitch, volume, rate and tone control, dramatic improvisations and simulations, as well as imitative techniques that impersonate someone's behaviour and speech. Furthermore, other suggested activities include tasks with picture imaging, as well as breathing and resonance exercises so that learners can gradually relax and start speaking more naturally.

Multisensory activities aim to help learners discover their learning style. This approach seems to be holistic - learners' senses are heightened by the use of all modalities: a) visual techniques include the use of pictures, tables, three-dimensional models, diagrams, colours, cards, photos; b) auditive techniques include intensive listening to recordings, association of various natural sounds to speech sounds, use of mnemonic devices; c) tactile techniques include the use of various objects to demonstrate elements in the sound system, for instance, a rubber band to demonstrate vowel length, a sheet of paper or feather to demonstrate aspiration, a membranophone instrument such as kazoo to demonstrate intonation contours, mirrors for self-inspection of the vocal tract, dentures for pointing out the place of articulation of consonants and the movement of the lower jaw; and d) kinaesthetic techniques include hand movements in the air for demonstrating intonation contours, using fingers to count the number of syllables, stomping with the feet to show the stressed syllable or rhythm in general, moving the facial muscles around the lips with hands to show lip position, etc.

Neurolinguistic techniques aim to strengthen the interpersonal relation between the teacher and the group or among peers by developing mutual trust and accepting positive suggestions and/or constructive criticism. These techniques include visualizations of speech sounds and phonological processes for memory improvement, reformulating 
negative experiences about pronunciation into more positive ones, remembering short catch phrases at the end of the class, etc.

\section{CONCLUSION}

Unlike other language skills, L2 pronunciation is "not tied to proficiency - a beginner can have excellent productions and an individual with a superb grasp of L2 syntax and vocabulary can be difficult to understand" (Thomson and Derwing 2015: 14). This in itself makes the process of learning L2 pronunciation "a complex task which requires motivation, time, and patience on the part of the learner and teacher" (Pennington and Rogerson-Revell 2019: 201). Choosing the most appropriate teaching technique requires that a teacher demonstrates sensitivity to additional factors not necessarily related to the development of proficiency. These concern not only understanding of the essential parts of pronunciation and how they interact in speech, but also taking into consideration the learners' age, their learning context, the communicative context, learners' goals and to what extent they are achievable, as well as learners' projected L2 identity and emotional state. The reality of this is certainly daunting for practicing teachers, and presents a serious challenge.

According to Henderson et al. (2012), the most common techniques ${ }^{2}$ used in European classrooms include listen-and-repeat, spontaneous error correction, reading aloud, and phonetic instruction/training. Compared to the types of teaching techniques found in the literature and categorized in our discussion, it is noticeable that traditional activities such as automatic repetition, ear-training and phonetic instruction are still considered beneficial. However, if teachers aim to teach their learners about the relevance of L2 pronunciation to successful spoken communication they also need to incorporate less conventional teaching techniques, such as activities for raising phonological awareness, communicative activities and techniques that adopt an interdisciplinary approach. Most importantly, they need to be critical of the abundance of pedagogic resources now on the market, and make informed choices based on related research and applicable results (Pennington and Rogerson-Revell 2019).

\section{BIBLIOGRAPHY}

BAKER, Ann (2006a) Tree or Three? An Elementary Pronunciation Course (2 ${ }^{\text {nd }}$ edition). Cambridge: Cambridge University Press.

BAKER, Ann (2006b) Ship or Sheep? An Intermediate Pronunciation Course (3 ${ }^{\text {rd }}$ edition). Cambridge: Cambridge University Press.

2 The study does not test the effectiveness of the listed teaching techniques. 
BOWEN, J. Donald (1980) Contextualizing pronunciation practice. A. Covell Newton (ed.), A TEFL Anthology: Selected Articles from the English Teaching Forum 197378. Washington, D.C.: English Teaching Division, 63-69.

BROWN, H. Douglas (1987) Principles of Language Learning and Teaching (2 ${ }^{\text {nd }}$ edition). Englewood Cliffs, NJ: Prentice Hall Regents.

BYRNE, Donn (1997) Teaching Oral English. London: Longman.

Cambridge Dictionary. 20 October 2019. https:/dictionary.cambridge.org/dictionary/ english/.

CATFORD, John Cunnison (2001) A Practical Introduction to Phonetics (2 ${ }^{\text {nd }}$ edition). Oxford: Oxford University Press.

CAULDWELL, Richard (2013) Phonology for Listening: Teaching the Stream of Speech. Birmingham: Speech in Action.

CELCE-MURCIA, Marianne/DonnaM.BRINTON/JanetM.GOODWIN(2007)Teaching Pronunciation: A Reference for Teachers of English to Speakers of Other Languages. Cambridge: Cambridge University Press.

Collins Online Dictionary. 20 October 2019. https://www.collinsdictionary.com/.

DALTON, Christiane/Barbara SEIDLHOFER (2001) Pronunciation. Oxford: Oxford University Press.

DERWING, Tracey M./Murray J. MUNRO (2005) Second language accent and pronunciation teaching: A research-based approach. TESOL Quarterly 39 (3), 379-397.

FLEGE, James Emil (2003) Assessing constraints on second-language segmental production and perception. A. Meyer and N. Schiller (eds.), Phonetics and Phonology in Language Comprehension and Production: Differences and Similarities. Berlin: Mouton de Gruyter, 319-355.

FRASER, Helen (2001) Teaching Pronunciation: A Handbook for Teachers and Trainers. Sydney: TAFE NSW Access Division.

GARCÍA LECUMBERRI, Maria Luisa/John A. MAIDMENT (2000) English Transcription Course. London: Edward Arnold.

GILBERT, Judy B. (2012) Clear speech: Pronunciation and Listening Comprehension in North American English ( $4^{\text {th }}$ edition). Cambridge, New York: Cambridge University Press.

GOODWIN, Janet (2001) Teaching Pronunciation. M. Celce-Murcia (ed.), Teaching English as a Second or Foreign Language ( $3^{\text {rd }}$ edition). Boston: Heinle Cengage Learning, 117-137.

HANCOCK, Mark (2005) English Pronunciation in Use: Intermediate. Cambridge: Cambridge University Press.

HANCOCK, Mark (2010) Pronunciation Games. Cambridge: Cambridge University Press.

HANCOCK, Mark (2017a) PronPack 1: Pronunciation Workouts. Chester: Hancock McDonald ELT. 
HANCOCK, Mark (2017b) PronPack 2: Pronunciation Puzzles. Chester: Hancock McDonald ELT.

HANCOCK, Mark (2017c) PronPack 3: Pronunciation Pairworks. Chester: Hancock McDonald ELT.

HANCOCK, Mark (2017d) PronPack 4: Pronunciation Poems. Chester: Hancock McDonald ELT.

HENDERSON, Alice/Dan FROST/Elina TERGUJEFF/Alexander KAUTZSCH/Deirdre MURPHY/Anastazija KIRKOVA-NASKOVA/Ewa WANIEK-KLIMCZAK/David LEVEY/Una CUNNINGHAM/Lesley CURNICK (2012) English pronunciation teaching in Europe survey: Selected results. Research in Language 10, 5-27.

HEWINGS, Martin (1993) Pronunciation Tasks: A Course for Pre-intermediate Students (Student's Book). Cambridge: Cambridge University Press.

HEWINGS, Martin (2007) English Pronunciation in Use: Advanced. Cambridge: Cambridge University Press.

HEWINGS, Martin (2011) Pronunciation Practice Activities: A Resource Book for Teaching English Pronunciation. Cambridge: Cambridge University Press.

JENKINS, Jennifer (2000) The Phonology of English as an International Language. Oxford: Oxford University Press.

KASHRU, Braj Bihari (1985) Standards, Codification and Sociolinguistic Realism: The English Language in the outer circle. R. Quirk and H. Widdowson (eds.), English in the World. Cambridge: Cambridge University Press, 11-30.

KELLY, Gerald (2003) How to Teach Pronunciation. Harlow: Longman.

KENWORTHY, Joanne (1990) Teaching English Pronunciation. Hong Kong: Longman. KIRKOVA-NASKOVA, Anastazija/Elina TERGUJEFF/Dan FROST/Alice HENDERSON/Alexander KAUTZSCH/David LEVEY/Deirdre MURPHY/Ewa WANIEK-KLIMCZAK (2013) Teachers' views on their professional training and assessment practices: Selected results from the English Pronunciation Teaching in Europe Survey. J. M. Levis and K. LeVelle (eds.), Pronunciation and Assessment: Proceedings of the 4th Annual Pronunciation in Second Language Learning and Teaching Conference. Aug. 2012. Ames, IA: Iowa State University, 29-42.

LAROY, Clement (1995) Pronunciation. Oxford: Oxford University Press.

LEVIS, John M. (2005) Changing contexts and shifting paradigms in pronunciation teaching. TESOL Quarterly 25 (3), 369-377.

LEWIS, Michael/Jimmie HILL (1999) Practical Techniques for Language Teaching. London: Language Teaching Publications.

Longman Dictionary of Contemporary English. 20 October 2019. https://www.ldoceonline.com/.

MACCARTHY, P. A. D. (1967) English Pronunciation. Cambridge: Cambridge University Press.

Macmillan Dictionary. 20 October 2019. https://www.macmillandictionary.com/. 
MAŃKOWSKA, Anna/Marta NOWACKA/Magdalena KŁOCZOWSKA (2009) “How Much Wood Would a Woodchuck Chuck? ”: English Pronunciation Practice Book. Kraków-Rzeszów-Zamość: Konsorcjum Akademickie.

MARKS, Jonathan/Tim BOWEN (2012) The Book of Pronunciation: Proposals for a Practical Pedagogy. Peaslake, Surrey, UK: Delta Publishing.

MORLEY, Joan (1991) The pronunciation component in teaching English to speakers of other languages. TESOL Quarterly 25 (3), 310-349.

MORTIMER, Colin (1995) Elements of Pronunciation: Intensive Practice for Intermediate and More Advanced Students. Cambridge: Cambridge University Press.

MUNRO, Murray J./Tracey M. DERWING (1995) Foreign accent, comprehensibility and intelligibility in the speech of second language learners. Language Learning 45, 73-97.

MUNRO, Murray J./Tracey M. DERWING (1998) The effects of speaking rate on listener evaluations of native and foreign-accented speech. Language Learning 48 (2), 159-182.

MUNRO, Murray J./Tracey M. DERWING (1999) Foreign accent, comprehensibility and intelligibility in the speech of second language learners. J. Leather (ed.), Phonological Issues in Language Learning. Oxford: Basil Blackwell, 285-310.

NILSEN, Don L. F./Alleen Pace NILSEN (2010) Pronunciation Contrasts in English (2 ${ }^{\text {nd }}$ edition). Long Grove, Illinois: Waveland Press, Inc.

NIXON, Caroline/Michael TOMLINSON (2009) Primary Pronunciation Box: Pronunciation Games and Activities for Younger Learners. Cambridge: Cambridge University Press.

Oxford Learner's Dictionaries. 20 October 2019. https://www.oxfordlearnersdictionaries.com/.

PENNINGTON, Martha C./Jack C. RICHARDS (1986) Pronunciation revisited. TESOL Quarterly 20 (2), 207-225.

PENNINGTON, Martha C./Pamela ROGERSON-REVELL (2019) English Pronunciation Teaching and Research: Contemporary Perspectives. London: Palgrave Macmillan.

REID, Eva (2016) Teaching English pronunciation to different age groups. R. Repka and M. Šipošová (eds.), Jazykovedné, literárnovedné a didaktické kolokvium XXXIXI: zborník vedeckých prác a vedeckých štúdii. Bratislava: Z-F LINGUA, 19-30.

ROGERSON-REVELL, Pamela (2011) English Phonology and Pronunciation Teaching. London: Continuum Press.

SAITO, Kazuya (2012) Effects of instruction on L2 pronunciation development: A synthesis of 15 quasi-experimental intervention studies. TESOL Quarterly 4 (4), 842-854.

TENCH, Paul (2011) Transcribing the Sounds of English. Cambridge: Cambridge University Press. 
THOMSON, Ron I./Tracey M. DERWING (2015) The effectiveness of L2 pronunciation instruction: A narrative review. Applied Linguistics 36 (3), 326-344.

TRIM, John (2001) English Pronunciation Illustrated. Cambridge: Cambridge University Press.

UNDERHILL, Adrian (2005) Sound Foundations: Learning and Teaching Pronunciation. Oxford: Macmillan Heinemann.

VAUGHAN-REES, Michael (2003) Test Your Pronunciation. Harlow: Penguin.

WALKER, Robin (2010) Teaching the Pronunciation of English as a Lingua Franca. Oxford: Oxford University Press.

WELLS, John C. (2006) Phonetic transcrption and analysis. K. Brown (editor-in-chief), Encyclopedia of Language and Linguistics. Vol. 9 ( $2^{\text {nd }}$ edition). Amsterdam: Elsevier, 386-396.

WREMBEL, Magdalena (2001) Innovative approaches to the teaching of practical phonetics. Proceedings of the PTLC 2001, 63-66. http://citeseerx.ist.psu.edu/viewdoc/ download?doi=10.1.1.539.4313\&rep=rep1\&type $=$ pdf.

\section{POVZETEK}

\section{Izgovorjava v tujem jeziku: pregled tehnik poučevanja}

Pričujoči prispevek ponuja kritičen pregled tradicionalnih ter sodobnejših tehnik in dejavnosti, ki so namenjene vadenju izgovorjave in so obravnavane v znanstveni literaturi. V preteklih desetletjih so teoretični pristopi k poučevanju izgovorjave doživeli pomembne spremembe: če so se sprva osredotočali predvsem na natančno oblikovanje oz. izgovorjavo posameznih glasov, sta danes $\mathrm{v}$ središču njihovega zanimanja sporazumevalni pomen tekočega govora in njegova razumljivost. Ker je poučevanje izgovorjave v drugem jeziku zahtevno, se ga je treba lotiti sistematično. Prispevek ponuja razmislek o različnih odločitvah, ki jih morajo učitelji sprejeti pri izbiri vaj za izgovorjavo: izbrati morajo vrsto fonološke strukture, ki naj jo vaja obravnava, določiti način govora in strukturno raven govora, na katero naj se vaja osredotoča, odločiti se morajo za vrsto vaje, opredeliti stopnjo nadzora nad strukturo, ki je predmet posamezne vaje, in določiti kognitivne veščine, ki naj bi jih spodbujalo izvajanje določene vaje. Analiza znanstvene literature je pokazala, da so se tehnike poučevanja izgovorjave prilagodile različnim sodobnim smernicam. Tako tradicionalne dejavnosti, kot so samodejno ponavljanje glasov, zaznavni trening in pouk fonetike, sicer še vedno veljajo za učinkovite, vendar je več poudarka tudi na dejavnostih za razvijanje fonološke zavesti, na sporazumevalnih dejavnostih in na tehnikah, ki se opirajo na interdisciplinarni pristop.

Ključne besede: ponavljanje glasov, zaznavni trening, pouk fonetike, fonološka zavest, sporazumevalne dejavnosti 


\begin{abstract}
The aim of the paper is to give a critical summary of the traditional and more alternative techniques and activities for pronunciation practice recommended in the literature. In the past few decades the theoretical approaches to teaching pronunciation have changed considerably, from giving a strong focus on the accurate production of individual speech sounds to shifting the focus onto the greater communicative relevance of connected speech and intelligibility. Approaching L2 pronunciation teaching is not an easy task, and it needs to be systematically dealt with. The paper discusses several decisions teachers need to make when choosing activities for pronunciation practice: selecting the type of phonological structure to practice, deciding on the speech mode, determining the structural level of practice, focusing on a particular type of instruction, establishing the degree of control of the structure that is practiced, and choosing which cognitive skill to enhance while practicing. With regard to the various techniques for teaching pronunciation, the analysis shows they have adapted accordingly in line with the different trends. Hence, while traditional activities such as automatic repetition, ear-training and explicit phonetic instruction are still considered effective, additional priority is given to activities for raising phonological awareness, communicative activities and techniques that adopt an interdisciplinary approach.
\end{abstract}

Keywords: sound repetition, ear-training, phonetic instruction, phonological awareness, communicative activities 